GLOBAL JOURNAL OF AGRICULTURAL SCIENCES VOL. 20, 2021:53-61

COPYRIGHTC BACHUDO SCIENCE CO. LTD PRINTED IN NIGERIA ISSN 1596-2903

\title{
SOCIO-ECONOMIC DETERMINANTS OF NET-INCOME IN FISH FARMING IN KAINJI LAKE BASIN, NIGERIA
}

OMEJE, JULIUS E., ACHIKE, ANTHONIA I., ARENE, CHUKWUEMEKA J., FALEKE, SUNDAY A. MANUWUIKE, QUEEN C. AND USMAN, GARBA A.

(Received 27 September 2021; Revision Accepted 26 October 2021)

\begin{abstract}
The study analyzed the socio-economic determinants of net-income in aquaculture of Kainji, Lake Basin, Nigeria. Specifically, the study examined the; fish farming systems; cost and returns, socio-economic determinants of net-farm income and challenges of fish farming in the area. The study adopted a two-stage sampling procedure to select 120 table-size fish farmers. Data were collected with questionnaires that were administered through face-to-face interview and analyzed using descriptive statistics, budgetary technique and multiple regression analysis. The results showed that $35.00 \%$ of the fish farmers were within the age bracket of $31-40$ years, $53.34 \%$ were men, $91.67 \%$ were married, $55.83 \%$ had between $1-5$ years of experience in fish farming and $75.83 \%$ had tertiary educational qualification. Majority (92\%) of the fish farmers practiced the monoculture of catfish using earthen ponds system. The estimated total expenses were $14,953,330.74$ while the total revenue generated from 9 fish ponds, each stocked with an average of 3883.986 fingerlings in 2 cycles per year was $\$ 20,188,142.00$. The estimated net-farm income after tax was $\# 5,234,811.26$ while the net profit margin and return on investment was $25.93 \%$ and $35 \%$ respectively. Age, experience and household size were positive and significant $(p<0.05)$ socio-economic factors that affected netfarm income while the challenges of fish farming were high cost of feed $(\bar{x}=3.24)$, poor pricing $(\bar{x}=3.11)$, poor access to capital $(\bar{x}=3.09)$ and persistent poaching/theft $(\bar{x}=2.67)$. Based on the findings of the study, it is recommended that there should be an intensive research by the fish nutrition division of National Institute for Freshwater Fisheries Research (NIFFR) on the possible alternatives of crude protein source that could be a perfect substitute to Clupeids in fish feeds.
\end{abstract}

KEYWORDS: aquaculture, catfish, socio-economic, profitability, farmers

\section{INTRODUCTION}

Aquaculture, the culture of fish and other aquatic organisms has become a major economic activity with great potentials of spearheading agricultural transformation. In Nigeria, it is mostly dominated by fish culture with Catfish (Clarias spp) the most cultured fish species (Asa and Obinaju, 2014). The practice of Aquaculture in Nigeria became necessary because of the shortfall in fish supply from capture fisheries, which cannot sustain the domestic demand for fish presently and in the foreseeable future.
The Fishery Committee for West and Central Africa Gulf of Guinea (FCWC), (2016) estimated that the total demand for fish in Nigeria was 3.2 million metric tons, while domestic supply was 800,000 metric tons based on the 2014 population estimate of 180 million people. In order to meet this shortfall, Central Bank of Nigeria (2017) reported that over 288 billion naira was spent on annual fish importation in Nigeria. This is because fish is major source of animal protein with a high level of Vitamin A (Fiedler et al. 2015); thus, making fish a good alternative of meeting the domestic demand for protein rich animal source of food. Furthermore, the continued

Omeje, Julius E., Division of Socio-economics and extension services, National Institute for Freshwater Fisheries Research, New Bussa, Niger State.

Achike, Anthonia I., Department of Agricultural Economics, University of Nigeria, Nsukka

Arene, Chukwuemeka J., Department of Agricultural Economics, University of Nigeria, Nsukka

Faleke, Sunday A., Division of Socio-economics and extension services, National Institute for Freshwater Fisheries Research, New Bussa, Niger State.

Manuwuike, Queen C., Division of Socio-economics and extension services, National Institute for Freshwater Fisheries Research, New Bussa, Niger State.

Usman, Garba A., Division of Socio-economics and extension services, National Institute for Freshwater Fisheries Research, New Bussa, Niger State. 
rise in fish import bill is unstainable especially in an economy dependent on revenue from unstable prices of crude oil export. In order to mitigate this alarming situation, Adeosun, Ume and Ezugwu (2019) proposed on the investment in viable aquaculture for the improvement of livelihoods and the protein requirement of people.

The rising level of fish farming activities in Kainji Lake Basin, Nigeria have shown that Nigeria is tapping into its huge potentials of fishery and aquaculture development as documented by FAO, (2015). However, understanding the socio-economic characteristics of the fish farmers is a key indicator of profitability analysis of the sector. Social factors such as gender, age, education level and household characteristics have been recognized to play an important role in sustainable aquaculture (Kundu, 2010). For instance, Omeje, Sule and Aguihe (2020) opined that aqua-culturists within the economically active age possess the potentials to expand for higher income. Onyekuru, Ihemezie and Chima (2019) gave an insightful thought that fish farmers with longer years of experience are expected to be more productive than those with shorter years of experience; while Adeosun et al. (2019) reported that the years of experience in fish farming and number of ponds per farmer were positive determinants of net farm income. On this note, Zacharia et al. (2013) opined that understanding these factors is important in policy formulation in aquaculture sub-sector as it allows refining management strategies to reflect the needs and aspirations of the people concerned. Hence, this study was pre-empted by limited information on the socioeconomic characteristics and profitability of aquaculture in Kainji lake Basin, Nigeria. Specifically, the study examined the socio-economic characteristics of the fish farmers, aquaculture systems, cost and returns, socioeconomic determinants of net-farm income and challenges of fish farming in the area.

\section{METHODOLOGY}

The study was conducted in Kainji Lake Basin, an area bounded on the south of Niger State and north of Kebbi State, Nigeria. The geographical coordinates of the area are Latitudes $9^{\circ} 50^{\prime}$ and $1^{\circ} 55^{\prime}$ North and Longitudes $4^{\circ}$ $23^{\prime}$ and $4^{0} 51^{\prime}$ East (Olokor, 2011). The Lake provides immense potential and opportunities for the development of aquaculture as there are over 3000 homestead earthen and concrete ponds currently in the area (Madu \& Ibiyo, 2011). Kainji lake comprise of about 316 fishing communities demarcated into 3 strata namely; upper stratum (northern basin), middle stratum (central basin) and lower stratum (southern basin).

The study adopted a two-stage sampling technique to select 120 respondents from a population of 229 tablesize fish farmers. The first stage involved the purposive selection of 20 communities across the three strata based on the high concentration of fish farming activities. The communities include Yauri, Rofia, Mahuta, Kokoli, Zamare, Utonu, Duga, Mashaya, T. Gungawa, Gafara, Wawu, Wara, New bussa, Monai, T. A. Danbaba, Musawa, Malale, T/Na'ilo, Shagunu and Cover Dam.

In the second stage, stratified random sampling was used to select 120 table-size fish farmers. From a population of 55, 27 and 147 fish farmers in the upper, middle and lower strata respectively; 30, 20 and 70 fish farmers were selected accordingly using stratified random sampling technique. The sample frame was retrieved from various fish farmers' associations in the area. A questionnaire was used to collect data through interview schedule. Data were analyzed using descriptive statistics such as; mean, percentage and pie charts. Also, budgetary techniques such as net farm income analysis, gross profit margin and return on investment (ROI) were used to determine profitability. Finally, multiple regression analysis was used to evaluate the socio-economic determinants of net-farm income and the models are specified as thus;

i. Linear function

$Y=\alpha+\beta_{1} X_{1}+\beta_{2} X_{2}+\beta_{3} X_{3}+\beta_{4} X_{4}+\beta_{5} X_{5}+\beta_{6} X_{6}+\beta_{7} X_{7}+\beta_{8} X_{8}+\epsilon$

ii. Semi-log function

$Y=\alpha+\beta_{1} \log X_{1}+\beta_{2} \log X_{2}+\beta_{3} \log X_{3}+\beta_{4} \log X_{4}+\beta_{5} \log X_{5}+\beta_{6} \log X_{6}+\beta_{7} \log X_{7}+\beta_{8} \log X_{8}+\epsilon$

iii. Double log function

$L \log Y=\log \alpha+\beta_{1} \log X_{1}+\beta_{2} \log X_{2}+\beta_{3} \log X_{3}+\beta_{4} \log X_{4}+\beta_{5} \log X_{5}+\beta_{6} \log X_{6}+\beta_{7} \log X_{7}+\beta_{8} \log X_{8}+\epsilon$

Where: $Y=$ Net-farm income ( $\mathbb{N}) ; X_{1}=$ Age (years); $X_{2}=$ gender ( $1=$ male, $0=$ female); $X_{3}=$ Experience (years); $X_{4}=$ Marital status ( $1=$ married, $0=$ otherwise); $X_{5}=Y$ ears in school (number); $X_{6}=$ Household size (number); $X_{7}=$ commodity price $(\mathbb{A})$; $\mathrm{X}_{8}=\operatorname{levy}(\mathrm{A}) ; \alpha=$ intercept; $\beta \mathrm{i}=$ coefficients; and $\epsilon=$ error term.

While the profitability indices were;

Net-Income After Tax (NIAT)=Revenue-Total Expenses; Net Profit Margin= (NIAT/Revenue) ${ }^{*} 100$ and Return on investment $(\mathrm{ROI})=\mathrm{NIAT} /$ Total expenses $($ investment per year). 


\section{RESULTS AND DISCUSSION}

\section{Socio-economic Characteristics of Fish Farmers}

The result showed that $35.00 \%$ of the table-size fish farmers were within the age bracket of $31-40$ years, $26.67 \%$ were within the age bracket of 26.67 years, $25.00 \%$ were within the age bracket of $41-50$ years and $13.33 \%$ were above 50 years of age. The mean age of the fish farmers was 38.8 years which corresponds to the findings of Akarue and Aregbor (2015) and Zacharia et al. (2013) who reported that $74.72 \%$ and $51.6 \%$ of fish farmers were aged between 21-40 years. This result indicates the dominance of "young aged" actors in the fish farming business. This is because fish farming is a lucrative business as reported by Ifejika et al. (2015); hence, the income and profit margins are good indicators for attracting young entrepreneurs in the aquaculture value chain.

The result on gender showed that $53.34 \%$ were men, $8.33 \%$ were women and $38.33 \%$ were youths with about $93.75 \%$ married. Even though the result showed that men were more than the other gender categories, the youths were well represented than the women in aquaculture activities. This result does not deviate from existing literature, as the study by Oluwasola and Ige (2015) reported similar result from data collected in Ibadan, Nigeria which indicates that $80 \%$ of catfish farmers were men.

The result on experience showed that $55.83 \%$ of the fish farmers had experience of $1-5$ years, $26.67 \%$ had experience of $6-10$ years, $15.00 \%$ had experience of $11-15$ years and $2.50 \%$ had experience of 15 years and above. Thus, indicating that about $82.5 \%$ of the fish farmers had experience of 1-10 years. Similar result by Ukpe et al. (2017) found that $60 \%$ of fish farmers had experience of 6-10 years. This is a good sign in the aquaculture of the area as the result shows that the fish farmers have a good number of years of experience in managing risks and others shocks that can possibly affect the business.

The level of formal education of the farmers showed that the majority $(75.83 \%)$ have attained tertiary level of education, $1.67 \%$ attained primary education while 22.5 $\%$ attained secondary education. A high literacy level in aquaculture have been established to enhance the management of fish farms through the adoption of improved farm practices (Agboola, 2011). The high literacy level in the area could be attributed to the presence of higher academic and research institutions such as Federal College of Freshwater Fisheries Technology, Federal college of wildlife management and National Institute for Freshwater Fisheries Research (NIFFR). Hence, graduates and trainees from these institutions must have put their knowledge into practice. The household size of table-size fish farmers showed that the majority $(70.83 \%)$ had household size of 1-5 persons, $22.51 \%$ had household size of $6-10$ persons, and $9.66 \%$ had household size of more than 10 persons. The mean household size was 5 which can be of great importance in meeting the labour requirements of fish farming such as feeding, environmental sanitation and the like. Similar studies on fish farming by Ukpe et al. (2017), Ogunmefun and Achike (2017) and Zacharia et al. (2013) observed that the majority of fish farmers had household sizes within the range of 1-5 persons. Household members serve as source of labour in fish farming operation such as feeding, environmental sanitation as well as entry point to fish farming enterprise. This assertion agreed with the finding of Ifejika (2013) that household members serve as labour, and entry point of learning fish farming enterprise among family members in Anambra, Delta, Oyo and Niger States of Nigeria. 
Socio-economic Characteristics of fish farmers

\begin{tabular}{llll}
\hline Variable & Frequency & Percent & Mean \\
\hline Age (years) & 32 & & 38.8 \\
$21-30$ & 42 & 26.67 & \\
$31-40$ & 30 & 35.00 & \\
$41-50$ & 16 & 25.00 & \\
$>50$ & & 13.33 & \\
Gender & 64 & & \\
Men (male > 35 years) & 10 & 53.34 & \\
Women (female >35 years) & 8.33 & \\
Youths (male/female <35 years) & 46 & 38.33 & \\
& & & \\
Marital Status & & & \\
Married & 110 & 91.67 & \\
Single & 10 & 8.33 & \\
& & & \\
Experience (years) & & & \\
$1-5$ & 67 & 55.83 & \\
$6-10$ & 32 & 26.67 & \\
$11-15$ & 18 & 15.00 & \\
$>15$ & 3 & 2.50 & \\
& & & \\
Level of Education & & & \\
Primary & 2 & 1.67 & \\
Secondary & 27 & 22.5 & \\
Tertiary & 91 & 75.83 & \\
Household Size (number) & & & \\
$1-5$ & 85 & 70.83 & \\
$6-10$ & 27 & 22.51 & \\
$11-15$ & 4 & 3.33 & \\
$>15$ & 4 & & \\
\hline
\end{tabular}

Source: Field survey, 2020

\section{Assessment of Fish Farming systems}

The information on the fish farming systems in Kainji Lake Basin is presented in Figure 1-4. From the figures, majority (92\%) of the fish farmers culture Catfish (Clarias spp) solely while $8 \%$ culture Catfish and Tilapia (Oreochromis niliticus). This implies that Catfish species still remain the most cultured fish in the area which affirms the findings of Adewumi (2015) that Catfish culture is the most dominant species of fish cultured in Nigeria. This is because Catfish adapts well to any variation in culture environment (Asa and Obinaju, 2014), and has no form of religious or cultural norms prohibiting its consumption in Nigeria; thus, making it a generally acceptable fish in Nigeria. However, there is need to intensify the introduction of other species of fish that can be cultured by the fish farmers for mass production. Furthermore, $80 \%$ of the fish farmers adopted the use of earthen pond system while $20 \%$ use the flow-through system of fish farming in the area. The result is consistent with the finding of Omeje et al. (2020) who reported that fish farmers around Kainji Lake Basin practice the use of earthen pond system. This is because, fishes that are cultured under earthen pond system tend to perform well because the culture environment is synonymous with their natural environment. Moreover, majority $(97 \%)$ of the fish farmers practice the monoculture of stocking catfish while $3 \%$ practice the polyculture of stocking Catfish with Tilapia. This is because monoculture allows the farmer to monitor the life-cycle of the fish accurately; unlike polyculture which allows for natural predation to take place, in addition to the problem of overcrowding of ponds due to the high prolificacy of Tilapia in ponds. Also, the result shows that $86 \%$ of the fish farmers feed and maintain the fish for at least 6 months as the ideal period for raising a matured table-size fish under good management practices. 


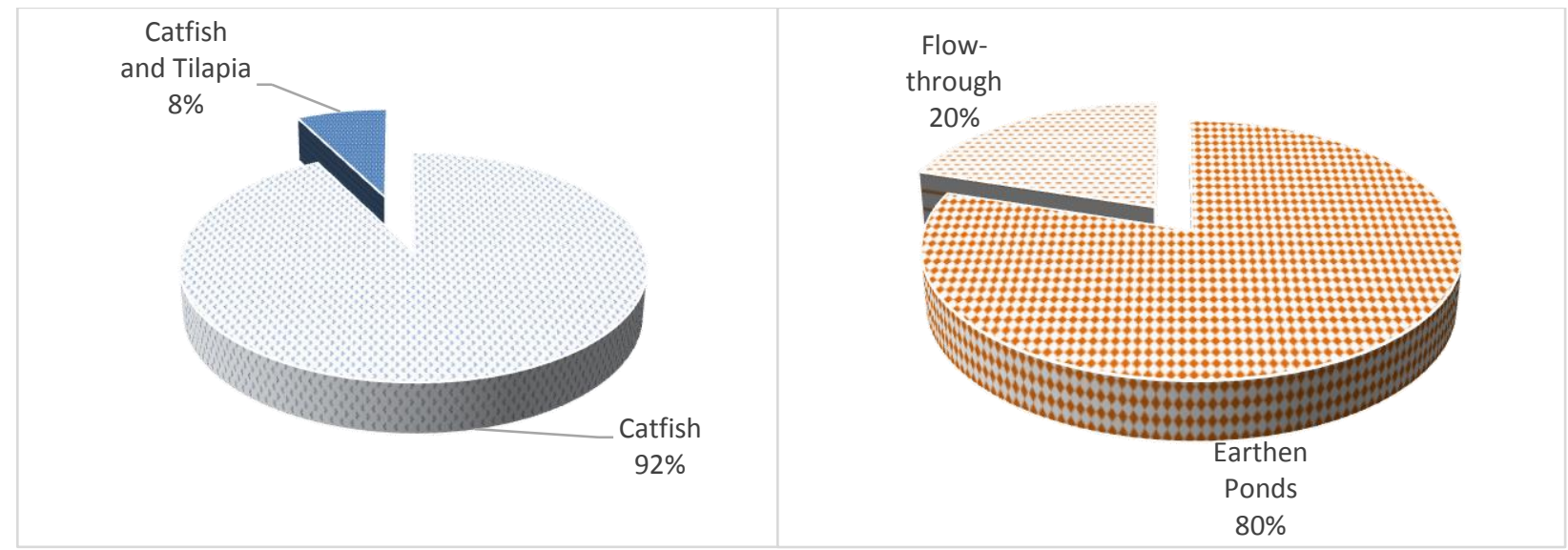

Figure 2: Species of fish cultured

Figure 3: Culture System Practiced

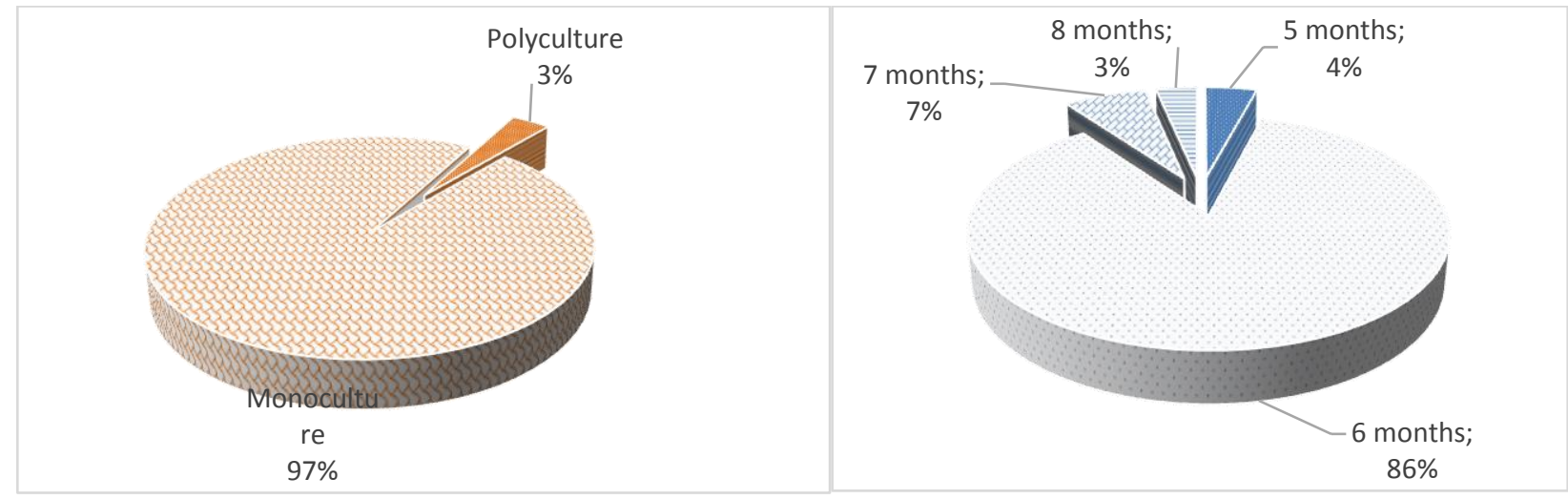

Figure 4: Fish culture Methods

Figure 5: Duration of culture

Source: Field survey, 2020

\section{Cost and Return Analysis in Fish Farming}

Table 2.1 and 2.2 presents the fixed cost, depreciation value of fixed items, expenses and profitability of fish farming in the area. The results showed that the

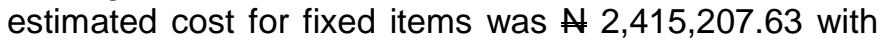
an annual total depreciation of $\mathbb{A} 55,283.38$. The estimated total operating expenses was $\mathrm{A}$ $14,898,047.37$ while the total expense (cost) incurred

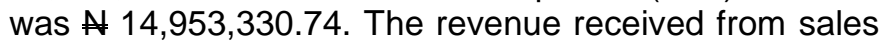
of table-size fish harvested from 9 ponds, each stocked with an average of 3883.986 fingerlings in 2 cycles per year was $A$ 20,188,142.00 while the net income and profit margin were $A 5,234,811.26$ and $25.93 \%$ respectively. The results imply that aquaculture in the area is profitable since the fish farmers were able to receive revenue in excess of total expense. The finding is supported by Omobepade et al. (2015) and Adeosun et al. (2019) who reported that aquaculture is a viable business. This is because the profit margin of $25.93 \%$ is an indication that to every $\$ 1$ received as revenue, the business generated 25.93 kobo as profit. Also, the return on investment of 0.35 (35\%) implies that to every A 1 invested in the fish farming business, 35 kobo was received as profit. This shows that aquaculture stand the chance of competing favourably with other agricultural products in Nigeria in terms of income, employment, poverty reduction and food security. Thus, agricultural transformation in the Nigeria should adopt strategies of developing sustainable aquaculture value chain especially in Nigeria. 

MANUWUIKE, QUEEN C. AND USMAN, GARBA A.

Table 2.1: Fixed cost schedule in aquaculture

\begin{tabular}{lllllll}
\hline \multicolumn{1}{c}{ Item } & $\begin{array}{c}\text { Unit of } \\
\text { Measurement }\end{array}$ & $\begin{array}{l}\text { Average } \\
\text { Quantity }\end{array}$ & Cost (N) & $\begin{array}{c}\text { Lifespan } \\
\text { (Years) }\end{array}$ & $\begin{array}{c}\text { Salvage } \\
\text { Value (N) }\end{array}$ & $\begin{array}{c}\text { Depreciation } \\
(\mathbf{N})\end{array}$ \\
\hline land & Plots & 7 & 896101.70 & - & - & - \\
Building and fittings & Bungalow & 1 & 353000.28 & 30 & 120000 & 7766.676 \\
Ponds & $15 \mathrm{~m} / 15 \mathrm{~m}$ & 9.0254237 & 270150.82 & 10 & 150000 & 12015.08 \\
Boreholes & 1000 feet & 1.3 & 613793.10 & 25 & 220000 & 15751.72 \\
Pumping machine and fittings & 3 horsepower & 1 & 140280.37 & 9 & 35000 & 11697.82 \\
Piping and accessories & 3inch PVC & 42 & 109881.36 & 15 & 30000 & 5325.424 \\
Scale & 50kg & 1 & 13800.00 & 15 & 5000 & 586.66 \\
Net & 3cm gear net & 1 & 18200.00 & 5 & 7500 & 2140 \\
Total & & & $\mathbf{2 4 1 5 2 0 7 . 6 3}$ & & $\mathbf{5 6 7 5 0 0}$ & $\mathbf{5 5 2 8 3 . 3 8}$ \\
\hline
\end{tabular}

Source: Computation from field survey, 2020

Note: Straight Line Method of Computing Depreciation $=($ Total Cost-Salvage Value $) /$ Lifespan

Table 2.2: Cost and return analysis in fish farming per 2 cycles in a year

\begin{tabular}{|c|c|c|}
\hline Item & Value (N) & $\%$ contribution to total cost \\
\hline $\begin{array}{l}\text { Revenue } \\
\text { A) } \mathrm{Kg} \text { of fish harvested per year } \\
\text { B) Price } / \mathrm{Kg} \\
\text { Revenue }=\mathbf{A}^{*} \mathbf{B}\end{array}$ & $\begin{array}{l}31960.83 \mathrm{Kg} \\
631.65 \\
\mathbf{2 0 1 8 8 1 4 2 . 0 0}\end{array}$ & \\
\hline $\begin{array}{l}\text { Stocking density } \\
\text { C) Number of ponds } \\
\text { D) Number of cycles/year } \\
\text { E) Number of fingerlings per pond } \\
\text { F) Price/fingerlings } \\
\text { Stocking }=C^{\star} D^{\star} E\end{array}$ & $\begin{array}{l}9.0254237 \text { (no.) } \\
2 \\
3883.986 \text { (no.) } \\
19.7 \\
70109 \text { (fingerlings) }\end{array}$ & \\
\hline $\begin{array}{l}\text { Expenses } \\
\text { Feed } \\
\text { Cost of Fingerlings }\left(C^{*} D^{*} E^{\star} F\right) \\
\text { Fertilizer/Cow dungs } \\
\text { Salt/ash } \\
\text { Electricity bill/Year } \\
\text { Depreciation } \\
\text { Fueling } \\
\text { Transport } \\
\text { Levies } \\
\text { Labour } \\
\text { Total Expenses }\end{array}$ & $\begin{array}{l}12823521.74 \\
1381152.00 \\
19014.00 \\
2213.95 \\
34881.82 \\
55283.38 \\
84572.18 \\
63188.97 \\
22800.00 \\
466702.70 \\
\mathbf{1 4 9 5 3 3 3 0 . 7 4}\end{array}$ & $\begin{array}{l}85.76 \\
9.24 \\
0.13 \\
0.01 \\
0.23 \\
0.37 \\
0.57 \\
0.42 \\
0.15 \\
3.12\end{array}$ \\
\hline $\begin{array}{l}\text { Net Income After Tax (NIAT) } \\
\text { Net Profit Margin } \\
\text { Return on Investment (ROI) }\end{array}$ & $\begin{array}{l}5234811.26 \\
25.93 \% \\
35 \%\end{array}$ & \\
\hline
\end{tabular}

Source: Computation from field survey, 2020

\section{Socio-economic determinants of net-farm income}

The result of the multiple regression analysis on the socio-economic determinants of net-farm income is presented in Table 3. The semi-log functional form was selected as the lead equation based on the magnitude of regression coefficients, number of significant variables and the of value $\mathrm{R}$-square. Firstly, the variable for age was positive and significant $(p<0.05)$ on net-farm income. This implies that an increase in the age of the farmers will result to an increase on net-farm income. According to Ngeywo, Basweti and Shitandi (2015), age is a significant factor to the level of profits realized by farmers. This is because the age of fish farmers is an indication to the level of fish farmer's maturity in the management of the day-to-day activities on the farm. Secondly, the variable for experience was significant $(p<0.05)$ and positively related net-farm income of the fish farmers. Fish farmers with longer years of experience possess the technicality on how to efficiently utilize production resources. This is because Zongli et al. (2016) reported that the years of experience was positively related to economic efficiency. The result was in agreement with that Adeosun et al. (2019) who reported that experience was positively related to netfarm income. Thirdly, household size was significant $(p<0.05)$ and positively related to net-farm income of the 
fish farmers. Ifejika (2013) reported that household members serve as labour and entry point for skill acquisition in fish farming. In most cases, family source of labour are unpaid, thus resulting to a lower production cost and higher profit margins.

Finally, the variable "commodity price" was statistically significant $(<0.01)$ and positively related to net-income of fish farmers. The price of a commodity has been shown to affect the income of farmers either positively or negatively (Demeke \& Balie, 2016) depending on the demand, quantity supplied and several other factors such as weather changes and biological crisis (Atozou \& Lawin, 2016). This means that under favourable conditions, an increase in the price of a commodity will positively result to an increase in income.
Other variables such as; gender, marital status, years in school and levy were not significant $(p<0.05)$. This implies that these variables were not important socioeconomic determinants of net-farm income in the study. However, the coefficient for the intercept was significant $(p<0.05)$ implying that there are other variables that were not included in the model which could be a significant derivative to net-farm income. The Adj Rsquared was 0.5084 which means that the variables included in the model were able to influence the variation of the dependent by $50.84 \%$ while the $\mathrm{F}$ statistic of $4.192>2.13$ shows that the independent variables collectively influenced the variation of the dependent

Table 3: Socio-economic determinants of net-farm income

\begin{tabular}{llll}
\hline Variables & Coefficients & Standard error & t \\
\hline Age & 0.313983 & 0.129294 & $2.42^{*}$ \\
Gender & 0.688993 & 0.532822 & 1.29 \\
Experience & 0.874041 & 0.440116 & $1.99^{*}$ \\
Marital status & 0.017821 & 0.16451 & 0.11 \\
Years in school & 0.058176 & 0.038016 & 1.53 \\
Household size & 0.485262 & 0.221428 & $2.19^{*}$ \\
Commodity price & 0.590180 & 0.160678 & $3.67^{\star * *}$ \\
Levy & -0.34529 & 1.435942 & -0.24 \\
Intercept & 0.175755 & 0.048737 & 3.606201 \\
\hline R-squared & 0.5413 & & \\
Adj R-squared & 0.5084 & & \\
F-Statistic & 4.192 & & \\
F-tabulated & 2.31 & & \\
Prob>F & $0.031^{*}$ & & \\
\hline
\end{tabular}

Source: computation from field survey, $2020{ }^{*}=\operatorname{sig}$ at $5 \%,{ }^{* *}=\operatorname{sig}$ at $1 \%$

\section{Challenges of fish farming}

The challenges of fish farming are presented in table 4. From the Likert-type scale analysis, high cost of feed $(\bar{x}=3.24)$ ranked first with the respondents suggesting that there should be an alternative for Clupeids as a source of crude protein in feed formulation. This is because there is a government restriction on the fishing of Clupeids because of the obnoxious method used by fishers; thus placing the fish spp (Clupeids) at risk of extinction in the area. Similarly, Ogunmefun and Achike (2017) found that high cost of feed was a great constraint to fish culture; this can be shown from the findings of this study as fish feed amounted to about $85.77 \%$ contribution to total cost of production. Other constraints to aquaculture in the area were poor pricing $(\bar{x}=3.11)$, poor access to capital $(\bar{x}=3.09)$ and persistent poaching/theft $(\bar{x}=2.67)$ which ranked second, third and fourth respectively.

\section{Table 4: Challenges of fish farming}

\begin{tabular}{llllll}
\hline S/N & Challenges & Mean & Rank & Inference & What can be done to solve this problem? \\
\hline 1 & Poor access to Capital & 3.09 & $3^{\text {rd }}$ & SC & Government should assist farmers with soft loans \\
2 & Poor water Management & 1.89 & $6^{\text {th }}$ & NSC & \\
3 & High cost of feed & 3.24 & $1^{\text {st }}$ & SC & There is need to provide substitute for clupeids \\
4 & Poor pricing & 3.11 & $2^{\text {nd }}$ & SC & $\begin{array}{l}\text { There should be functional associations to assist } \\
\text { in price regulation }\end{array}$ \\
& & & & & \\
6 & Poor quality fingerlings & 2.39 & $5^{\text {th }}$ & MC & \\
6 & Persistent poaching/theft & 2.67 & $4^{\text {th }}$ & SC & The security architecture should be improved \\
7 & Insecurity of life & 1.67 & $8^{\text {th }}$ & NSC & \\
8 & High cost of labour & 1.84 & $7^{\text {th }}$ & NSC & \\
\hline
\end{tabular}




\section{CONCLUSION AND RECOMMENDATION}

The study established that fish farmers in Kainji Lake Basin, Nigeria were mostly men within the economic active age, had good formal educational background and number of years of experience in fish farming. Thus, implying that fish farming in the area has a favourable socio-economic potentials for development and expansion. Also, the budgetary analysis shows that fish farming is a viable business with high level of turnover. Generally, to transform agriculture in Nigeria will require identification and provision of impeccable solutions to the problems of the stakeholders involved in all the value chains. In this case, aquaculture development and sustainability in Nigeria will require a holistic approach by bringing together the stakeholders such as; the fish farmers, government (Research Institutes), NGOs, community leaders, financial institutions and local security organizations. This will enable them draft out implementable measures that will strengthen the confidence of fish farmers in their aquaculture activities. Such measures include but not limited to; formation of fish farmers' cooperative or associations, ease of access to credit from financial institutions, intensive research on cost-effective and environmentally friendly inputs and the strengthening of local security outfits in various communities. This public-private partnership must be transparent in resource delivery and sharing of information on fish data for effective tracking and forecasting.

\section{REFERENCES}

Adeosun, K. P., Ume, C. O. and Ezugwu, R. U., 2019. Analysis of socio-economic factors of fish pond production in Enugu State, Nigeria. Journal of Tropical Agriculture, 57(1), 27-34.

Adewumi, A. A., 2015. Aquaculture in Nigeria: Sustainability issues and challenges. Direct Research Journal of Agriculture and Food Science, 3(12), 223-231.

Agboola, W. L., 2011. Improving fish farming productivity towards achieving food security in Osun State, Nigeria: A socioeconomic analysis. Annals of Biological Research, 2(3), 62-74.

Akarue, O. B. and Aregbor O. E., 2015. Socio- economic analysis of catfish farming in Uvwie Local Government Area, of Delta State, Nigeria. International Journal of Innovative Agriculture and Biology Research, 3(3), 33-43.

Asa U. A. and Obinaju, L. C., 2014. Economics of catfish production in Akwa Ibom State, Nigeria. Global Journal of Management and Business Research: B Economics and Commerce, 14(3), 23-28.

Atozou, B. and Lawin, K. G., 2016. Impact of the Farm Income Stabilization Insurance Programme on production decisions in the Quebec pork industry: an empirical and theoretical analysis. Sustainable Agricultural Research, 5(4), 94106.
Central Bank of Nigeria CBN. 2017. CBN annual report.

Demeke, M. and Balie, J., 2016. Assessment of national policies in developing countries to combat and mitigate the effects of agricultural markets' excessive price volatility. In et al. Garrido (Ed.), Agricultural Markets Instability: Revisiting the Recent Food Crisis pp. 161-177. Routledge, London and New York.

Food and Agricultural Organization [FAO], 2015. National Aquaculture Legislation Overview: Nigeria. Retrieved from; http://www.fao.org /fishery /legalframework/nalo nigeria/en

Fiedler, J. L., Lividini, K., Drummond, E. and Thilsted, S. $\mathrm{H}$., 2015. Strengthening the contribution of aquaculture to food and nutrition security: The potential of a vitamin A-rich, small fish in Bangladesh. Aquaculture, 452(2016), 291-303. Retrieved from www.elsevier.com/locate/aquaculture.

Fishery Committee for the West Africa Gulf of Guinea, (FCWC), 2016. Nigeria fishery statistics.

Ifejika, P. I., Asadu, A. N., Enwelu, I. A., Sanni, A. O., Nwabeze, G. O. and Omeje, J., 2015. Determining youth choice of enterprise in aquaculture production for job creation in Abia State, Nigeria. Nigerian Journal of Fisheries, 12(1), 809-914.

Kundu, R., 2010. Assessment of socio-economic factors affecting small scale fish farming in Busia District, Kenya. Eldoret, Kenya.

Madu, C. T. and Ibiyo, L. M. O., 2011. Aquaculture development and its potentials for future development in Lake Kainji Area. In. Raji, A., Okaeme, A. N. and Ibeun M. O. (Ed.), Forty years on Lake Kainji Fisheries Research pp. 198-210. New Bussa, Niger State: National Institute for Freshwater Fisheries Research.

Ngeywo J., Basweti, E. and Shitandi, A., 2015. Influence of gender, age, marital status and farm size on Coffee production: A Case of Kisii County, Kenya. Asian Journal of Agricultural Extension, Economics and Sociology, 5(3), 117-125.

Ogunmefun, S. O. and Achike, A. I., 2017. Socioeconomic characteristics and constraints of pond fish farmers in Lagos State, Nigeria. Agricultural Science Research Journal, 7(10), $304-317$.

Olokor, J. O., 2011. Geography and climate of Kainji Lake Basin. In. Raji, A., Okaeme, A.N \& Ibeun M. O. (Ed.), Forty years on Lake Kainji Fisheries Research (p. 11). New Bussa, Niger State: National Institute for Freshwater Fisheries Research. 
Oluwasola, O. and Ige, A. O., 2015. Factors determining the profitability of catfish production in Ibadan, Oyo State, Nigeria. Sustainable Agriculture Research, 4(4), 57-65.

Omeje, J. E., Sule, A. M. and Aguihe, E. O., 2020. An assessment of aquaculture table-size fish farmers activities in Kainji Lake Basin, Nigeria. Agro-Science Journal of Tropical Agriculture, Food, Environment and Extension, 19(2), 3640.

Omobepade, B. P., Adebayo, O. T., Amos, T. T. and Adedokun, B. C., 2015. Profitability analysis of aquaculture in Ekiti State, Nigeria. Nigerian Journal Agric. Food Environ., 11(1), 114-119.

Onyekuru, N. A., Ihemezie, E. J. and Chima, C. C., 2019. Socioeconomic and profitability analysis of catfish production: a case study of Nsukka Local Government area of Enugu State, Nigeria. Agro-Science Journal of Tropical Agriculture,
Food, Environment and Extension, 18(2), 5158.

Ukpe, U. H., Audu, N. D., Djomo, C. R. F. and Akise, O. G., 2017. Economics of catfish farming in selected Local Government Areas of Taraba State, Nigeria. Innovative Techniques in Agriculture, 2.3(2017), 376-382.

Zacharia, S., Jacob, W., Samuel, C., Likuyani, K. H., Okoth, P., Maina, J. and Wakaanya, A., 2013. Socio economic characteristics and practices of fish farmers in western Kenya. Elixir International Journal of Management Arts, 56(2013), 13387-13394. Retrieved from www.elixirpublishers.com.

Zongli, Z., Yanan, Z., Feifan, L., Hui, Y., Yongming, Y and Xinhua, Y. (n.d.). Economic efficiency of small-scale tilapia farms in Guangxi, China. Aquaculture Economics and Management, 114. 